\title{
Study of Soil Properties and Physical Land Characteristics of Corn Farmland in Gorontalo Regency, Gorontalo Province
}

\author{
Sri Maryati \\ Department of Earth Science and Engineering \\ Faculty of Mathematics and Natural Sciences \\ Universitas Negeri Gorontalo \\ Gorontalo, Indonesia \\ Corresponding email: sri.maryati@ung.ac.id \\ Sunarty Eraku \\ Department of Earth Science and Engineering \\ Faculty of Mathematics and Natural Sciences \\ Universitas Negeri Gorontalo \\ Gorontalo, Indonesia
}

\begin{abstract}
Corn is the main commodity in the category of food crops other than cassava, sweet potatoes, peanuts and soybeans in the Gorontalo Regency. Based on The Gorontalo Province in Figures 2016, corn production of Gorontalo Regency 2015 was 142863 ton and total harvested area was 26817 hectare. Corn productivity in Gorontalo Regency 2015 was $53.27 \mathrm{kw} / \mathrm{ha}$, the productivity of corn exceeded productivity targets 2016 set by the Ministry of Agriculture $52.62 \mathrm{kw} / \mathrm{ha}$. The purpose of this study is to examine the soil physical properties, soil chemical properties, soil biological properties, and physical land characteristics of corn farmland in the Gorontalo Regency. Data in this study were collected by observation and measurement of the physical land characteristics on the field, soil sampling, and laboratory analysis. Selection of samples was based on the land unit principle. The analysis method used is the quantitative analysis and descriptive analysis. The results showed that the topography, soil conditions, and land conservation system of corn farmland vary widely in the Gorontalo Regency. It determines the corn productivity in the Gorontalo Regency.
\end{abstract}

Keywords-Soil properties, physical land characteristics, corn farmland

\section{INTRODUCTION}

Agriculture is a major sector in the Gorontalo Regency. In line with the government program of Gorontalo Province, namely corn based agropolitan program, Gorontalo Regency also put corn as a major commodity. It is also supported by Gorontalo people's habits that make corn as basic food besides rice. Based on The Gorontalo Province in Figures 2016, corn production of Gorontalo Regency 2015 was 142863 ton and total harvested area was 26817 hectare. Corn productivity in Gorontalo Regency 2015 was 53.27 kw/ha, the productivity of corn exceeded productivity targets 2016 set by the Ministry of Agriculture $52.62 \mathrm{kw} / \mathrm{ha}$. The corn crop is spread over 19 districts in Gorontalo. Based on The Gorontalo Regency in Figures 2016, the largest corn producer includes Tibawa Sub District with corn production was 25,234.30 ton; Bongomeme Sub District with corn production was 24,787.80 ton; and Mootilango Sub District with corn production was 19,091.40 ton (BPS - Statistics of Gorontalo Regency, 2016).

Corn was selected as key of agricultural commodities for agropolitan program to sustain the economy of the community in Gorontalo Province based on several things including the corn has a short life 115 days so that the harvest can be obtained quickly, historically corn is the basic food of the Gorontalo society, the public got used to cultivate corn, as well as there is market demand for corn. The results research by Jocom et al (2009) showed that the agropolitan program increase farmers' income through various interventions from the government.

Corn demand in Indonesia is predicted to continue to increase and the corn has a strategic role for both national food security and other industries as well as its role in economic growth so that production must be increased. The occurrence of corn evenly throughout the 19 sub-districts indicates that the corn is easily to be cultivated in the district of Gorontalo. The cultivation of the corn could increase rural society incomes in the Gorontalo Regency, which is largely dependent on the agricultural sector. Hence, Gorontalo Regency should be able to maintain and to increase the production of corn, harvested area, as well as the productivity per year. But the increase in corn production should be respectful to environmental sustainability.

The land preservation for corn cultivation should be taken seriously by the government as stakeholders and farmers as land users. All activities in development must pay attention to the environment, including the cultivation of agricultural crops. 
In the context of corn cultivation in the Gorontalo Regency, the implementation should take into account the soil properties and physical land characteristics so that land degradation can be avoided. Land degradation that may arise is the erosion which will cause soil fertility reduction, and may even lead to critical lands.

It is crucial to have serious attention because most of the Gorontalo Regency area has a moderate steep slope (15-25\%), steep $(25-40 \%)$ and very steep (>40\%). Besides, land clearing and conversion of land for the cultivation of the corn tend to increase in the Gorontalo Regency. The productivity of the corn crop could be optimal if the plants get the optimal conditions for growth. Optimal plant growth is determined by the land capability, land suitability, land improvement techniques, as well as the appropriate land conservation techniques.

The purpose of this study is to examine the soil physical properties, soil chemical properties, soil biological properties, and physical land characteristics of corn farmland in the Gorontalo Regency. The results of this study are very useful for decision-making for land improvement techniques, appropriate conservation techniques, as well as the determination of interventions to improve the productivity of corn in Gorontalo Regency. Data in this study were collected by observation and measurement of the physical land characteristics on the field, soil sampling, and laboratory analysis. Selection of samples was based on the land units' principle. The analysis method used is the quantitative analysis and descriptive analysis.

\section{METHOD}

\section{A. Study Area}

This study was conducted in Gorontalo Regency, Province of Gorontalo, Indonesia. In term of geographic location, Gorontalo Regency is located between $00^{\circ} 30^{\prime}-00^{\circ} 54^{\prime}$ North Latitude and between $122^{\circ} 07^{\prime}-123^{\circ} 44^{\prime}$ East Longitude. Gorontalo Regency is bordered to the east with Bone Bolango Regency and Gorontalo City, bordered to the west with Boalemo Regency, bordered to the north with North Gorontalo Regency, and bordered to the south with Tomini Bay. The area of Gorontalo Regency is $2.125,47 \mathrm{~km}^{2}$. Gorontalo Regency area is 17 percent of the total land area of the Gorontalo Province. Gorontalo Regency consists of 19 sub districts. Map of study area is showed in Fig. 1.

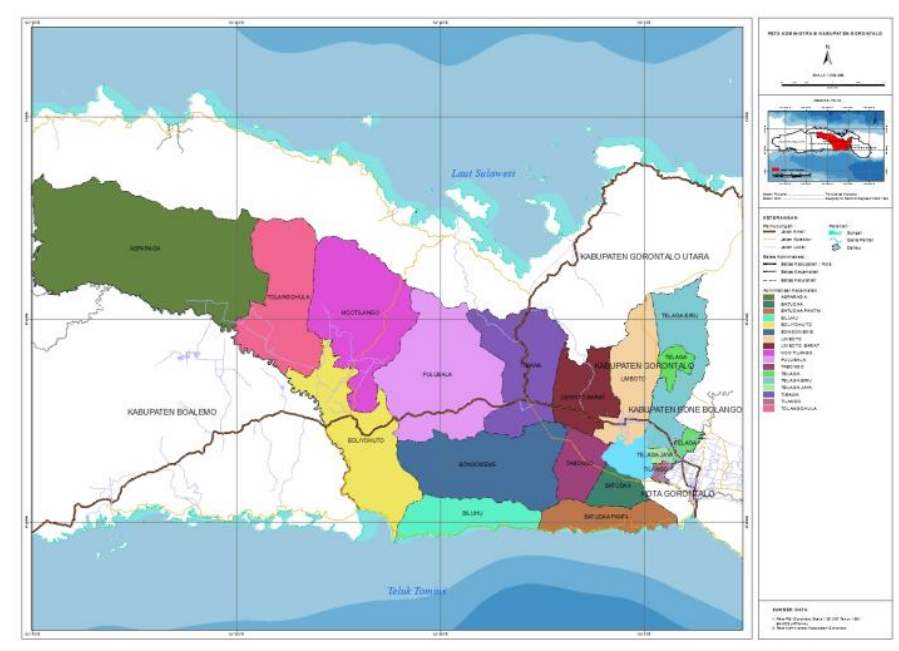

Fig. 1. Map of Study Area

\section{B. Data Collection}

The observed parameters in this study include soil properties and physical land characteristics. Indicators were observed for soil properties namely soil texture, organic contents, cation exchanges capacity, and essential nutrients. Indicator were assessed for the physical land characteristics include topography, slope, flood risk, soil erosion risk, coarse material, land cover, and soil tillage.

Those indicators were collected by observation and measurement in the field, soil sampling, soil laboratory analysis, quantitative and descriptive analysis. Determination of sample points was performed using land units approach which was conducted by overlay multiple maps includes landform, slope and soil using ArcGIS 10 software.

\section{FINDING AND DISCUSSION}

This research was conducted by observation, measurement and data collection in the field. The numbers of sample points in this study are 10 sample points which were determined using land unit approach. The sample points represent the entire landform, topography, and soil types of corn farmland in Gorontalo Regency. The research results are presented in the following sections:

\section{A. Soil Texture}

Soil texture determines porosity, infiltration, permeability, consistency, drainage, water and air movement, and erodibility. Hence it will influences type of land tillage, soil erosion control technique and soil conservation method. Soil texture in the study area varies according to the size and percent of soil fraction. The soil textures in the study area are clay, clay loam, loam, sandy loam, sandy clay, and sandy clay loam. Clay was dominated study area and was characterized by very small particle size $(<0.02 \mathrm{~mm})$ and low infiltration capacity that causes high surface run off which is flowing over the soil and carrying soil particles. 


\section{B. Organic Matter}

Percent of soil organic matter is very important in agricultural industry. It affects soil fertility which is influencing plant growth. The soil organic matters analyzed in this study consist of percent of carbon and percent of nitrogen to calculate $\mathrm{C} / \mathrm{N}$ Ratio. Table 1 shows the percent of soil organic matter and the $\mathrm{C} / \mathrm{N}$ Ratio in the study area. Based on Table 1, Percent of Corganic in the study area range from 0.78 to 3.18 and Percent of $\mathrm{N}$ range from 0.09 to 0.11 .

TABLE 1. SOIL ORGANiC MATtER AND THE C/N RATIO

\begin{tabular}{|c|c|c|c|}
\hline Location & \% of C & \% of N & C/N Ratio \\
\hline 1 & 1.56 & 0.09 & $17: 1$ \\
\hline 2 & 2.16 & 0.09 & $24: 1$ \\
\hline 3 & 3.14 & 0.1 & $31: 1$ \\
\hline 4 & 2.91 & 0.1 & $29: 1$ \\
\hline 5 & 2.14 & 0.11 & $19: 1$ \\
\hline 6 & 1.79 & 0.1 & $18: 1$ \\
\hline 7 & 2.23 & 0.11 & $18: 1$ \\
\hline 8 & 1.79 & 0.1 & $8: 1$ \\
\hline 9 & 0.78 & 0.1 & $19: 1$ \\
\hline 10 & 1.91 & 0.1 & Source: field survey and laboratory analysis, 2016 \\
\hline
\end{tabular}

\section{Soil pH, Cation Exchange Capacity, and Base Saturation}

Soil $\mathrm{pH}$ is a degree of acidity or alkalinity of soil. Soil is indicated as an acid soil if the $\mathrm{pH}$ below than 7.0 and indicated as an alkaline soil if the $\mathrm{pH}$ is greater than 7.0. The soil $\mathrm{pH}$ of the study area ranges from 5.97 to 7.27 . Soil $\mathrm{pH}$ influences availability of nutrients, availability of microorganism, and soil toxicity. Cation exchange capacity (CEC) associated with percent of organic matter and indicates soil fertility. The cation exchange capacity (CEC) of the study area ranges from 4.96 to $65.29 \mathrm{cmol}$. Base saturation in the study area ranges from 72 to $100 \%$. Table 2 shows soil $\mathrm{pH}$, cation exchange capacity, and base saturation in the study area.
TABLE 2. SoIL PH, CATION EXCHANGE CAPACITY, AND BASE SATURATION

\begin{tabular}{|c|c|c|c|}
\hline Location & Soil pH & $\begin{array}{c}\text { Cation Exchange } \\
\text { Capacity }\end{array}$ & Base Saturation \\
\hline 1 & 7.05 & 14.37 & 100 \\
\hline 2 & 6.89 & 31.34 & 85 \\
\hline 3 & 6.69 & 42.74 & 80 \\
\hline 4 & 7.22 & 65.29 & 92 \\
\hline 5 & 7.27 & 23.75 & 100 \\
\hline 6 & 6.65 & 20.14 & 74 \\
\hline 7 & 6.35 & 13.5 & 67 \\
\hline 8 & 6.22 & 11.89 & 67 \\
\hline 9 & 6.01 & 4.96 & 80 \\
\hline 10 & 6.36 & 16.44 & Source: field survey and laboratory analysis, 2016 \\
\hline & & & \\
\hline
\end{tabular}

\section{Essential Nutrients}

Soil essential nutrients that were observed in this study include $\mathrm{K}, \mathrm{Ca}, \mathrm{Na}$ and $\mathrm{Mg}$ that are very important to maintain soil fertility. Result of laboratory analysis for essential nutrient in the study area was shown in Table 2. Based on Table $3, \mathrm{Ca}$ in the study area varies from 2.64 to $44.49 ; \mathrm{Mg}$ ranges from 0.63 to 4.83 ; $\mathrm{K}$ varies from 0.01 to 0.17 and $\mathrm{Na}$ varies from $0.01-0.03$. The result of $\mathrm{Ca}, \mathrm{Mg}, \mathrm{K}$ and $\mathrm{Na}$ contents could used for making decisions about the type of fertilizer should be supplied to the plant or the need for special treatment for soil and plants.

TABLE 3. SOIL ESSENTIAL NUTRIENTS

\begin{tabular}{|c|c|c|c|c|}
\hline Location & Ca & Mg & K & Na \\
\hline 1 & 14.99 & 1.18 & 0.01 & 0.03 \\
\hline 2 & 21.72 & 4.83 & 0.02 & 0.03 \\
\hline 3 & 31.38 & 2.74 & 0.17 & 0.02 \\
\hline 4 & 44.49 & 2.31 & 0.2 & 0.02 \\
\hline 5 & 18.85 & 2.9 & 0.13 & 0.02 \\
\hline 6 & 17.11 & 3.97 & 0.04 & 0.03 \\
\hline 7 & 8.61 & 1.27 & 0.12 & 0.02 \\
\hline 8 & 7.86 & 1.66 & 0.02 & 0.02 \\
\hline 9 & 2.64 & 0.63 & 0.04 & 0.02 \\
\hline 10 & 9.8 & 1.18 & 0.04 & 0.01 \\
\hline
\end{tabular}

\section{E. Topography}

Topographical condition is one of the main factors to be considered in various types of land use, including the cultivation of agricultural crops. The topography of the land determines soil development process, infiltration, soil erodibility level, land capability and land suitability. Topography observed in this study includes surface relief and slope. In the context of corn cultivation, topography will affect 
planting techniques, soil management techniques, and soil conservation techniques should be applied to the corn farmland.

Based on observations in the field, it was found that corn crop at Gorontalo Regency planted in almost all classes of slope including $0-3 \%, 3-8 \%, 8-15 \%, 30-40 \%$ and $>40 \%$. Photos showing the corn planting in various classes of slope are shown in Fig 2 and Fig 3.

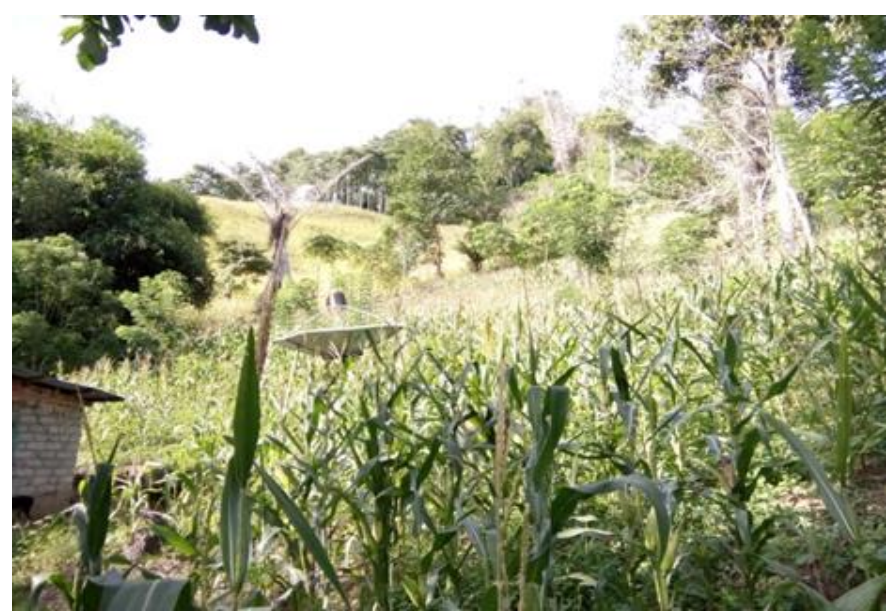

Fig. 2. Corn planting in slope $>45 \%$

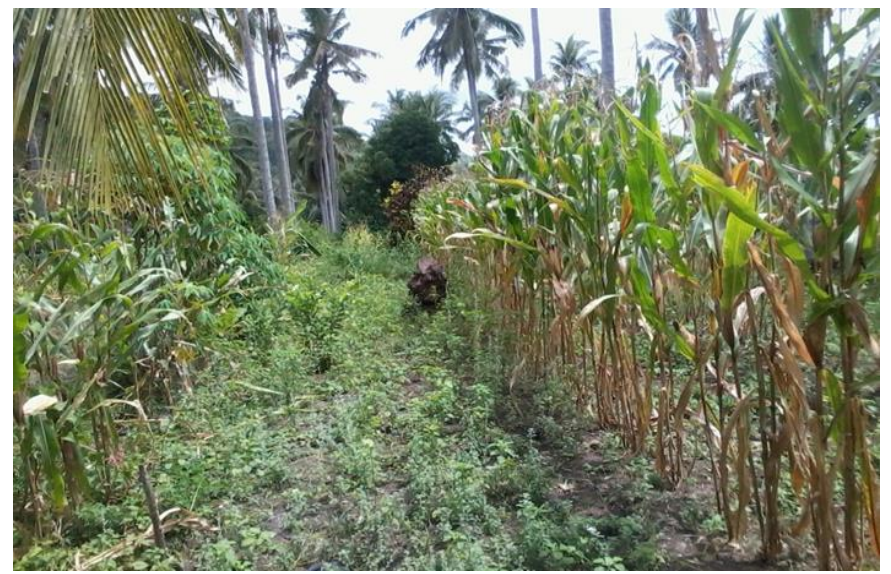

Fig. 3. Corn planting in slope $8-15 \%$

\section{F. Rock and Outcrop}

This study also observed the occurence and percentage of rock and outcrop in the soil surface. This is considering both of these indicators will determine the land suitability for corn cultivation. Based on the criteria of land suitability for corn crops, the land would be very suitable if the rock and outcrop is $<5 \%$, and would be suitable if rock and outcrop is 5-15\%. Field observations in the study area indicate that the rock and outcrop are $<5 \%$ and $5-15 \%$, based on these parameters the study area is in a class very suitable and suitable for corn cultivation.

\section{CONCLUSION AND SUGGESTIONS}

After the data from field observation and soil laboratory result were analyzed, this research makes the following conclusions:

- The soil textures in the study area are clay, clay loam, loam, sandy loam, sandy clay, and sandy clay loam.

- Percent of C-organic in the study area range from 0.78 to 3.18 and Percent of $\mathrm{N}$ range from 0.09 to 0.11 .

- The soil $\mathrm{pH}$ of the study area ranges from 5.97 to 7.27 , the cation exchange capacity (CEC) ranges from 4.96 to $65.29 \mathrm{cmol}$ and base saturation ranges from 72 to $100 \%$.

- In the context of soil essential nutrients, $\mathrm{Ca}$ in the study area varies from 2.64 to $44.49 ; \mathrm{Mg}$ ranges from 0.63 to 4.83; $\mathrm{K}$ varies from 0.01 to 0.17 and $\mathrm{Na}$ varies from 0.01 -0.03 .

- Based on observations in the field, it was found that corn crop at Gorontalo Regency planted in almost all classes of slope including $0-3 \%, 3-8 \%, 8-15 \%, 30-40 \%$ and $>$ $40 \%$.

- Field observations in the study area indicate that the rock and outcrop are $<5 \%$ and $5-15 \%$, based on these parameters the study area is in a class very suitable and suitable for corn cultivation.

\section{ACKNOWLEDGMENT}

The authors' wish to express their deepest gratitude to Directorate General Higher Education, Ministry of Research, Technology and Higher Education Indonesia for research funding. The authors also acknowledge Rector of Universitas Negeri Gorontalo, Head of Institute for Research and Community Services Universitas Negeri Gorontalo, and Dean of Faculty of Mathematics and Sciences for permit and support to attend the $19^{\text {th }}$ Annual Scientific Meeting of Indonesian Geographers Association (IGI).

\section{REFERENCES}

[1] BPS - Statistics of Gorontalo Province, "Gorontalo Province in Figures 2016,” BPS - Statistics of Gorontalo Province : Gorontalo, 2016

[2] BPS - Statistics of Gorontalo Regency, "Gorontalo Regency in Figures 2016," BPS - Statistics of Gorontalo Regency: Gorontalo, 2016.

[3] S. Anugrah, "Pembangunan Perekonomian Perdesaan Berbasis Agribisnis Jagung di Provinsi Gorontalo," Analisis Kebijakan Pertanian Volume 8 No 4, Desember 2010, pp.363-382.

[4] S. G. Jocom, E. I. K. Putri, and H. Hariyoga, "Dampak Pengembangan Agropolitan Basis Jagung dan Partisipasi Masyarakat di Provinsi Gorontalo: Kasus Kabupaten Pohuwato,” Forum Pascasarjana Vol. 32 No. 2 April 2009:103-116.

[5] Kementerian Pertanian, "Petunjuk Teknis Gerakan Pengembangan Jagung Hibrida 2016," Direktorat Jenderal Tanaman Pangan Kementerian Pertanian: Jakarta, 2015.

[6] Balai Besar Litbang Sumberdaya Lahan Pertanian, "Jagung (Zea mays)," Retrieved from http://bbsdlp.litbang.pertanian.go.id/kriteria/ jagung, 2016. 